\title{
Graduates Attributes: Convergence and Divergence of Different Stakeholders
}

\author{
Vallipuram Kanagasingam ${ }^{1}$ \\ ${ }^{1}$ Faculty of Commerce \& Management, Eastern University, Sri Lanka \\ Correspondence: Vallipuram Kanagasingam, Faculty of Commerce \& Management, Eastern University, Sri \\ Lanka.E-mail: Kana692002@yahoo.co.in, kanagasingamv@esn.ac.lk \\ Received: August 26, 2017 \\ doi:10.5539/ijbm.v13n1p288
}

\begin{abstract}
The concept of graduates' attributes has become the focus of increasing attention among practitioners and scholars alike. Little research, however, has been undertaken to investigate the graduates' attributes in Sri Lanka from the perspective of stakeholder, the main objective of this study is to explore students' attributes from different stakeholders' point of view, particularly scholars and industrialist perspective. Further, this study concludes that most employers are looking for graduates who possess a range of generic skills and attributes, particularly, communication, team work, critical thinking and problem-solving skills. The study found that graduates are unable to find suitable employment opportunities to fulfill their expectations. They have dissatisfaction towards the employability. The main reason for unemployment and under-employment among the graduates is due to mismatch between the qualities of graduates produced by the state Universities in Sri Lanka and the quality expected by employers.
\end{abstract}

Keywords: Graduates' attributes, Communication Skills, Team work

\section{Introduction}

Higher education has been expected as a major component that contributes to society by improving the quality of human life (Tang, Sachin \& Chen 2010). Where knowledge production, institutional autonomy and academic freedom are vital features in the conventional universities, it is not only in Sri Lanka but also in the rest of the world (Rasmussen, 2007). Universities around the world have already shifted and shift from pure research to the production of employable graduates in the current era. Universities have moved from pure knowledge centres to market centres for example producing employable graduates. With the rise of neoliberalism, the employability of graduates has become a more important goal of universities than ever before (Feller \& Irwin, 1997).” Thus, the inability of universities to produce employable graduates is considered a critical issue. Producing employable graduates is becoming challenging task for all higher education today. Expectations of employers are continually increasing to match the global environmental requirements. Graduate unemployment becomes a universal problem that is not an exception for Sri Lanka. Therefore, producing employable graduates has become one of the primary functions of universities (Feller \& Irwin, 1997; Hommadi, 1990; World Bank, 2012).

Problems regarding unemployed and underemployed graduates in Sri Lanka are not a new phenomenon, which has been reported since the academic year 1959/60. The average overall employability ratio of Universities in Sri Lanka is $54 \%$ (Nawaratne, 2012). The faculties of Arts and Management have higher rates of unemployment in the country and accounted for $76 \%$ and $36 \%$ of unemployed graduates respectively, whereas Medicine and Engineering accounted for $10 \%$ and $7 \%$ respectively in 2012 .

Graduate unemployment or underemployment, according to Wickramasinghe (2010), is due to a mismatch between the aspirations of graduates and the employment opportunities available to them. Further, previous studies have indicated that a mismatch between supply and demand conditions for graduate employment is due to the supply driven education system, which produces graduates who are not suited to labour market conditions (Ranasinghe, 1992; Forest, 2003; Central Bank of Sri Lanka, 2003; Weligamage \& Siengthai, 2003; Ariyawansa, 2008).

\section{Understanding the Graduates' Attributes}

As noted by Boulton \& Lucas (2011), "Universities create new possibilities; in teaching, they shape new people". 
One of the fundamental pillars of a university is to teach people. Universities train students in both disciplinary and non-disciplinary knowledge. Therefore, graduates exit within the university environment and become equipped with the necessary tools to tackle the world's contemporary problems (Boulton \& Lucas, 2011). Further, Boulton \& Lucas (2011) emphasise that graduates must fulfil the present requirements of global industries. Particularly, skills that universities impart to their graduates are given as follows: "universities serve to make students think" and "they are taught to question interpretations", which equates to analytical thinking skills. "Students are also taught to seek out what is relevant to the resolution of a problem" which represents problem solving skills. "Skills are the qualities which every society needs in its citizens" and this equates to social responsibility, and perhaps even teamwork as a skill required for societies to function effectively. Knowledge, skills and general attitudes are referred to as attributes of graduates. Therefore, employability of graduates is tightly bound up with graduates' attributes which are perceived by different stakeholders differently. There are diverse definitions of graduate attributes by different scholars. Nevertheless, the most suitable definition for the purpose of this research is given below.

"[T]he qualities, skills and understandings a university community agrees that its students should develop during their time with the institution. These attributes include but go beyond the disciplinary expertise or technical knowledge that has traditionally formed the core of most university courses. They are qualities that also prepare graduates as agents of social good in an unknown future" (Bowden, Hart, King, Trigwell, \& Watts, 2000).

The above graduates' attributes are defined by incorporating two main types of attributes: (a) those which pertain to an individual's capacity for citizenship (including involvement in the democratic processes, social cohesion, equity and human rights and ecological sustainability) and thus the ability to contribute towards a well-functioning society (Rychen \& Salganik, 2005); and (b) those which pertain to an individual's capacity to obtain and maintain work (Harvey, 2000; McQuaid \& Lindsay, 2005) and thus contribute to economic productivity.

Barrie (2007) constructs these attributes by researching the activities of academics responsible for developing graduate attributes as part of the university curriculum. He identifies five clusters of personal, cognitive, and applied skills that form the graduate attributes: research and inquiry: graduates of the university will be able to create new knowledge and understanding through the process of research and inquiry; information literacy: graduates of the university will be able to use information effectively in a range of contexts; personal and intellectual autonomy: graduates of the university will be able to work independently and sustainably, in a way that is informed by openness, curiosity and a desire to meet new challenges; ethical, social and professional understanding: graduates of the university will hold personal values and beliefs consistent with their role as responsible members of local, national, international and professional communities; and communication: graduates of the university will recognize and value communication as a tool for negotiating and creating new understanding, interacting with others, and furthering their own learning" (Barrie, Hughes \& Smith, 2009) .

Barrie at al., (2009) explains that these five clusters help to support graduates in being engaged global citizens those graduates who value scholarship and lifelong learning. Presently, graduate attributes are very important criteria to measure the achievement rates of graduates' employability of any higher educational institution. A single accepted universal definition has not been given to define graduate attributes (Barrie, 2007; Barrie, at al., 2009). Many researchers view graduate attributes to be the university-recognized core values and skills that students should have upon graduation, in order to become moral citizens (Bowden et al., 2000 cited in Barrie et al., 2009). They are also the skills that employers look for in today's labourers. The attributes of graduates that are demanded by the industry are twofold: technical knowledge and skills, and generic attributes. Generic attributes cover soft skills, personal attributes and values, which all graduates should acquire irrespective of their area of study in order to get employment.

According to Bowden et al. (2000 cited in Barrie 2006), graduate attributes are qualities, skills and understanding. The university community agrees that its students should develop these graduate attributes during their time with the universities. Stakeholders have different views about graduate attributes based on their experiences and perceptions. Different stakeholders have different views about graduate attributes, and views of two stakeholders may not be similar, and when there is a contradiction between the stakeholders it leads to attribute mismatch which has been highlighted by previous researchers as a main reason for unemployed graduates.

According to the contemporary literature, the 34 attributes/skills listed below are grouped into 09 categories and these are expected from graduates, especially from management graduates, by their employers. Different terminologies including, generic and specific attributes; workplace competencies and foundation competencies; 
workplace skills and personal attributes and values; functional skills and adaptive skills; technical knowledge and skills, and generic attributes; personal skills and functional skills; soft skills and hard skills; technical skills and employability skills; Interpersonal skills and intra personal skills, within literature, have been used to categorize these attributes Bowden, et al., 2000; Ismail, 2011)

The researcher further categorizes in Table 1, all 34 attributes into three major groups, namely, Conceptual, Human and Technical attributes in order to examine graduate attributes of management graduates of Sri Lankan State universities.

Table 1. Expected graduates' attributes from the graduates

\begin{tabular}{|c|c|c|}
\hline Conceptual Attributes & Human Attributes & Technical attributes \\
\hline Decision-making skills & Positive attitude & $\begin{array}{l}\text { Self-management (Punctuality and Time } \\
\text { Management) }\end{array}$ \\
\hline $\begin{array}{l}\text { Ability to organize and plan } \\
\text { Ability to be creative and } \\
\text { innovative }\end{array}$ & $\begin{array}{l}\text { Team working } \\
\text { Problem solving and decision skills }\end{array}$ & $\begin{array}{l}\text { Business and customer awareness } \\
\text { Communication and literacy }\end{array}$ \\
\hline Ability to initiate (be a self-starter) & Ability to adapt and be flexible & Application of numeracy \\
\hline Ability to work independently & Leadership skills & Application of information technology \\
\hline Visioning & Interpersonal skills & Administrative skills \\
\hline Ability to conceptualize & Personal strengths & Quantitative/mathematical skills \\
\hline Researching ability & Assertive Personality & $\begin{array}{l}\text { Oral communication skills and Presentation } \\
\text { skills }\end{array}$ \\
\hline Planning and organizing & Physical wellbeing & Learning skills \\
\hline Analytic skills & Ethical thinking skills & Technical skills \\
\hline \multirow[t]{3}{*}{ Risk-taking skills } & & Report writing (Written communication) \\
\hline & & Research / Inquiring skills \\
\hline & & English Language Competency \\
\hline
\end{tabular}

Sources: constructed by the researcher, 2015

When comparing the importance of and prioritizing these skills, communication, team work, leadership, English Language Competency and Computer literacy and IT skills are identified as commonly expected attributes for recruiting Management graduates by employers (Herok et al., 2013). As noted by Herok et al. (2013), among these, the literature further indicates that communication skills are considered very important by all employers, followed by industrial knowledge and critical thinking skills which come in second and third respectively. However, Herok et al. (2013) noted that specialist knowledge is not perceived to be centrally important to these industrial employers.

\section{Methodology of the Study}

For this study a qualitative approach has been used. This approach works best for understanding social phenomena. This study deals with various stakeholders. Researcher, therefore, understood that interviews and focus group discussion are the best ways to collect appropriate information for this study. During the period from February to July 2015, data was collected through interviews and focus group discussion throughout Sri Lanka. This approach enabled a discourse analysis methodological approach to interviewees. This meant that respondents were able to discuss their thoughts on Graduates Attributes: Convergence and Divergence of Different Stakeholders in Sri Lanka. The interviews also enabled more extended responses where interviewees discussed their experiences, attitudes and understanding of graduates attributes. For this study purposive sampling technique has been employed. The sample size of interviewees was 29 and three focus groups discussion also.

\section{Finding and Discussion}

The findings of the study reveal similarities and dissimilarities in perceptions among the main stakeholders (students, academics and the industrialists). The divergences create mismatch of skills among graduates which leads to unemployment among them. Knowledge, skills and attitudes are the main components of any training or 
academic programs which are commonly expected from the graduates. Although knowledge is given in the present curriculum, skills and attitudes are not properly provided to the graduates. The graduates would be recruited not only for the knowledge, but also for attitude, communication and other soft skills. The employer prefers to recruit graduates based on the above. Recruitment, however, is much limited since those attributes including communication skills are not presently available among graduates while having been good in subject knowledge. Throughout the interview process, two participants from difference universities pointed that:

"Perfect graduates are not only with knowledge part we links with skills also, Knowledge, skills and attitudes in this system skills and attitudes are not address properly with the traditional curriculum"(SL 3).

"Sometime they may recruit because of their English knowledge, the way they speak but not because of their knowledge on the subject area. So, those who need that communication skill priority, communication skills they may recruit those people" (SL 4).

In fact, job providers line with two quotations. Private companies in the globalized job market mainly concentrate on skills such as IT, English and application of management techniques. Despite present the curriculum consists of IT, English and management application, these are not sufficient enough to fulfill their requirements. In the academic discourse, (another) other respondent expresses that the produced graduates should be marketable like a product. Therefore, creativity and innovation are core ingredients in a graduate. When we compare with other disciplines, the product- management graduate must have creative skills. In addition, with the above views about employable graduates, one of the academics indicated that management graduates should have capacity to provide new ideas or concepts to businessmen for producing new products to the market. The statement below illustrates,

"I think the Business faculties should do they need to create new ventures; they need to create new managers, and entrepreneurs some things like that. The students, they do not capacity to bring the product to the market by providing knowledge and skills to initiate the capacity and the capital everything so we can develop the product as a marketable product" (SL2).

At the same time, SL 3 reveals that graduates generally depend on others, for example, they depend on lecture notes, guidance, decision making. On the other hand, they should be pragmatic, that is, the management graduate is to be an open graduate who must not be guided by others, rather that they ought to guide others.

"Employable graduate means working under someone so we need a social group to guide them. They should be open graduates" (SL 3).

Further, participant explained that a graduate should be open minded which denotes the attitudes of accepting any relevant job according to the qualifications, instead of waiting to join an executive position or government job for his / her specialized degree. It is most appropriate to the Sri Lankan scenario as there is no particular job earmarked for graduates, while the certain degree is considered as a professional degree as the MBBS in medicine, and B.Sc. in Engineering.

But, graduates of the universities prefer to work in private sectors where the attitudes among most of the undergraduates have been changed, compared to the past. An academic says;

"For our student our nations, now is good, 8 years ago, I asked the how many of you like government that time lot of, now I don't know arts student but my management students are most like join the private sectors. So means that a somewhat somehow they change their attitudes, that right so they like some challenges they are ready take challenges yes that's good things" (SL 3).

In spite of a little bit in the change of attitudes of management graduate to work in the private sector, still they are lacking due to other types of attitudes, such as dependency on others as indicated by SL 3. Therefore, the views of the academics show that the following attributes of the graduates' employability are influenced by attributes such as IT literacy, English fluency, Management knowledge with practical exposure or internship, Critical thinking and research components or research skill, Soft skills, Application of technology, Creativity, Change of attitude, Extra hard work, thinking out of the box, risk taking, creativity, research competencies, extra-curricular activities, English language presentation skills, Interviewee skills and communication skills.

In summary, attributes of graduates of the universities are focusing under knowledge, skills and attitudes, when academics assess the market condition, particularly graduates' labour markets, skills, attitudes and practical knowledge are not perfectly given to the graduates, while having theoretical knowledge is comparatively high among the graduates. The perfect graduate is expected with skills, knowledge and attitudes to match with the requirements of the labour market. These views were indicated by the academics concerned with the private sector's expectation from the graduates of State universities in Sri Lanka. Reasons to focus on the private sectors 
are discussed next.

\subsection{Actual status of the Attributes of Graduates at the Universities in Sri Lanka}

According to the views of the academics, the university is not fulfilling all the expectations of the graduates. Graduates are unable to find suitable employment opportunities to fulfill their expectations such as reasonable income, job security and social recognitions. They have dissatisfaction towards the employability. The main reason for unemployment and under-employment among the graduates is due to mismatch between the qualities of graduates produced by the state Universities in Sri Lanka and the quality expected by employers. This has been realized by the academics as well as university higher authorities such as University administration, University Grants Commission and the Ministry of Higher Education. They have already taken certain initiatives to resolve this problem in the graduates' employment markets in Sri Lanka. Most of the companies are directly or indirectly dealing with global organizations. Hence, they wish to recruit graduates with a global mind to think globally and act locally. Such qualities of graduates are not produced by the universities. Therefore, graduates are not matched to companies' requirements. Another academic also expressed the same view about the present status of the graduates, but his argument is something different from the previous views. According to his view, numbers of graduates are more in the labour markets (Excess supply) and demand for the graduate is less, which leads to unemployment in the market.

"We have some limitation with our graduates' lack of communication skills and lack of languages skills, So now, the problem is, we need to teach English and we needs to teach business ethics, every things in the curriculum. So that is a problem"(SL 2).

The graduates are not satisfied with the expectations of the private sector due to structure of present curriculum. But interviewee SL 1 stated that lack of industrial links with the university is one of the reasons for the management faculty being unable to deliver the right graduates to match the employers' expectations. Therefore, the main reasons for the present situation are academics and curriculum of universities in Sri Lanka which are given below:

"University academia should alien right curriculum as well as the delivery to be matched with the needs of the, let say of the stakeholders" (SL 1). "May be you know that 36 course units he has studied but he cannot come out with the output of report of the self-evaluation report of the company. Because that exposes not given, not given that is the quality"(SL 1).

According to SL 1, views of the academics, the students are completing numbers of credits for the degree but they are not given exposure in a qualitative way, and they are unable to perform at the private sectors. At the same time, another interviewee stated that the present degree programmes is knowledge based, which is not enough to satisfy the industry's needs. Industries are hiring employees, mainly concentrating on attitudes. Even though knowledge could be developed through the traditional curriculum, attitude has been ignored in the curriculum. The curriculum is to be developed to produce a complete character, which is illustrated below,

"My point is we have a big barrier we thought providing on the knowledge students not that not enough you must try to produce the complete character" (SL 3).

The above statement explored two aspects. First, graduates are not capable to apply for the jobs in large companies. Second, large companies are not willing to hire the local graduates for their jobs. Both reasons indicated that the local graduates are not suitable for large as well as multi-national companies. Therefore, according to the views of the academics, the actual graduates of the universities in Sri Lankan are having certain drawbacks such as low quality, lack of skills including communication skills and soft skills, no current knowledge, negative attitudes, dependents and lack of industrial exposure. All these drawbacks are established due to the main courses of the curriculum of the degree programmes, and the stand of the Academics in the Sri Lankan State Universities.

\subsection{Employers' Views about the Attributes of Graduates}

The views of the employers about the purpose of universities are to produce graduates who are suitable for their future manpower in the organizations. The following attributes are expected from the potential candidates: critical thinking, communication skills, leadership, ability to understand the work environment, analytical skills, confidence, risk taking, ability to change, facing changes, and being practical.

The purpose of the universities has been focused by the employers in consideration of the present condition, and future trends of the country and the world. Particularly, the employability of graduates is compared with knowledge, skills and attitudes of the candidates who are coming from foreign universities and those who have professional qualifications. When they compare the performance in the selection process, those who have 
graduated from universities are not performing well according their required standard. On the other hand, the foreign graduates are performing better than their expectations. Hence, they are giving priority to the foreign graduates or professionally qualified, which was defined by one of the employers.

"We do recruit large number graduates to the banks. Of Course the recent passed out graduate is limited, we are restructuring now however in the past, I did analysis, we attend to recruit 70 to $80 \%$ foreign graduates, the reason behind is in summary, confidence, ability to change, ability to adopt, face to change and what we learned in the class room is how to apply in business context" (EMP 5).

This narration clearly states that foreign graduates and the professionals have the attributes such as confidence, ability to adopt, face to change and application skills in the real work environment.

Another employer mentioned that:

"In case academic outputs of university, we have an experience: curriculum as well as prepares of graduates for the all industry. Time is not stand: industries are changing today year and years, and environment is changing very fast whether the changes permits in to curriculum fast to know. Likewise graduates change sufficiently. Likewise, Graduates have trained to adopt the changes sufficiently. End of the day I believe cover the universities any of us would be outdated within two or three years maximum" (EMP 8).

According to the view of one employer, the graduate should have the following skills such as English, practical management and confidence:

"Most of graduates are coming with very theoretical knowledge, but when it to come to application, one is a communication problem, some of are very fear in jobs, not confidence, no team work." (EMP2).

Further, other employers believed that the employability of graduates must have different kinds of attributes which are not given by the universities in Sri Lanka today. These attributes are expected by the employable graduates from the universities, with the expectation of the onus to be expected to perform by the organization to go with the fast global changes, and compared with the global management graduates who are graduated from abroad, or colleges or local foreign affiliated universities, and the professionally qualified candidates.

This evidence shows that private sector expectation is far ahead from the university's output. They are very fast to respond to the changes of the external environmental factors.

When summarize the views about the attributes of graduates of Management Faculties by the employers, they should produce graduates with critical thinking, communication skills, leadership, and ability to understand the work environment, analytical skills, confidence, risk taking, ability to change, face to change and being practical. These attributes are to be developed among the future graduates in order to produce employable graduates in the Management Faculties in Sri Lanka. According to the views of the academics and employers about the employable graduates who ought to have all the above mentioned characteristics, but graduates from the management faculties in Sri Lanka are not having such characteristics. All these attributes are expressed by the respondents from both sides, which related to knowledge, skills and attitudes of the graduates. The management degree programmes failed to provide adequate levels of knowledge, for example, lack of practical knowledge, skills, for example, lack of research skills, lack of communication skills, lack of leadership skills and lack of language skills, and the attitudes - for example, dependent attitudes of the students and negative attitudes.

All these above attributes are theoretically connected with the managerial attributes in an organization such as conceptual, human and technical, for example critical thinking, thinking capacity, research skills, and risk taking and confidence are treated as conceptual level attributes; understanding human nature, values, ethics and team work are treated as human skills, and how to handle the situation, understand the environment, achieve the target and work with positive attitudes with work and the people and so on are treated as technical aspects.

\section{Conclusion}

What are these abilities that make a graduate employable? Analytical thinking, problem solving, teamwork, ethics and social responsibility, and communication are called generic or transferable skills - the skills that can be applied in any context in the working environment. They are generally known as graduate attributes. Universities have reacted in a number of ways to address the employability of graduates. In the UK, universities offer skills development to their undergraduates, either by embedding these skills within the existing course curricula or by offering standalone, parallel courses. In Australia, for example, universities announce that they provide students with graduate attributes via their public websites (Douma, \& Schreuder, 2002). and it is "assumed that most courses have graduate attributes embedded in disciplinary knowledge and learning" (Green, Kraemer, Fugelsang, Gray, \& Dunbar, (2010, P.47). However, the answer to the question whether graduates in 
state universities in Sri Lanka are actually graduating with these attributes or not remains vague (Barrie, 2005).

Observing these findings as a whole, shows that most employers are looking for graduates who possess a range of generic skills and attributes, particularly, communication, team work, critical thinking and problem-solving skills.

\section{References}

Ariyawansa, E. (2008). Employability of Graduates of Sri Lankan Universities. Sri Lankan Journal of Human Resource Management, 2(1).University of Kaleniya.

Barrie, S. C. (2007). A conceptual framework for the teaching and learning of generic graduate attributes'. Studies in Higher Education, 32(4), 439-458.

Barrie, S., Hughes, C. \& Smith, C. (2009). The National Graduate Attributes Project: Integration and Assessment of Graduate Attributes in Curriculum. Strawberry Hills, NSW: Australian Learning and Teaching Council.

Bowden, J., Hart, G., King, B., Trigwell, K., \& Watts, O. (2000). Generic Capabilities of ATN University Graduates. Retrieved from http:/www.clt.uts.edu.au/ATN.grad.cap.project.index. html.

Central Bank of Sri Lanka. (2003). Central Bank Annual Report. Retrieved from http://www.lanka.Net/centralbank

Douma, S., Schreuder, H. (2002). Economic Approaches to Organizations (3rd ed.). Pearson Education: Harlow. Relevant chapters: 3 Organizations.

Feller \& Irwin. (1997). Technology Transfer from Universities. In John Smart (Ed.), Higher Education: Handbook of Theory and Research. NewYork: Agathon Press.

Forest, C. (2003). Empowerment skills for family workers: A worker handbook. Cornell University.

Green, A. E., Kraemer, D. J., Fugelsang, J. A., Gray, J. R., \& Dunbar, K. N. (2010). Connecting long distance: Semantic distance in analogical reasoning modulates frontopolar cortex activity. Cerebral Cortex, 20, 70-76. https://doi.org/10.1093/cercor/bhp081

Herok, G. H., Chuck, J. A., \& Millar, T. J. (2013). Teaching and Evaluating Graduate Attributes in Science Based Disciplines. Creative Education, 4(7), 42-49. https://doi.org/10.4236/ce.2013.47A2008.

Hommadi, A. H. (1990). University in the third World, Perception in Planning and Management. Indian Stateation Bureau, New Delhi, 66-67.

Kanagasingam,V. (2017). Coordination and Cooperation between State Universities and the Industries in Sri Lanka. Proceeding of 1st international conference in Accounting researchers and Educators, Department of Accounting, University of Kelaniya. 116-135.

McQuaid, R. W., \& Lindsay, C. (2005). The concept of employability. Urban Studies, 42(2), 197-219.

Nawaratne, S. J. (2012). Shifting paradigms of higher education in Sri Lanka. Re-creating and re-positioning of Sri Lankan Universities to meet emerging opportunities and challenges in a globalized environment, Workshop Proceedings. New German Critique. Retrieved from http://www.jstor.org/stable/488273

Ranasinghe, S. W. (1992). Human resource development in Sri Lanka: present trends and future perspectives.

Rasmussen, P. (2007). Learning and Communicative Rationality; The Contribution of Jürgen Habermas, Working papers on learning 6. Department of Education, Learning and Philosophy, Aalborg University.

Rychen, D. S., \& Salganik, L. H. (Eds.). (2003). Key Competencies for a Successful Life and a Well-Functioning Society. Göttingen, Germany: Hogrefe \& Huber.

Tang, Y., Sachin, S., \& Chen, X. F. (2010). Empowering Students with Engineering Literacy and Problem solving through Interactive Virtual Reality Games. 2nd International IEEE Consumer Electronics Society Games Innovation Conference, Hong Kong, Dec. 21-23.

Weligamage, S., \& Siengthai, S., (2003). Employer needs and graduate skills: The gap between employers' expectations and job expectations of Sri Lankan University graduates. $9^{\text {th }}$ International Conference on Sri Lanka Studies. Paper submitted.

Wickramasinghe, V. (2010). Graduates, University lecturers and employers' perceptions towards employability skills. Education and Training, 52(3), 226-244. Emerald group publishing Limited.

World Bank Discussion Paper Series. (2012). Sri Lanka as an education hub for international students: The road 
ahead. South Asia: Human development unit. Report No. 50.

\section{Copyrights}

Copyright for this article is retained by the author(s), with first publication rights granted to the journal.

This is an open-access article distributed under the terms and conditions of the Creative Commons Attribution license (http://creativecommons.org/licenses/by/4.0/). 